\title{
RELATION BETWEEN BUSINESS PROCESS MANAGEMENT MATURITY AND INNOVATION IN THE FINANCIAL SECTOR
}

\author{
Harmen Gerrit (Harold) van de Kamp ${ }^{1}$, Kobus Smit ${ }^{2}$ and Pascal Ravesteijn ${ }^{2}$ \\ ${ }^{1}$ e-office, The Netherlands \\ ${ }^{2}$ HU University of Applied Sciences, The Netherlands
}

\begin{abstract}
To survive in the increasing globalization competition, companies are required to continuously increase their productivity and enhance innovation. To realize this enhanced productivity, Business Process Management (BPM) maturity models are often used to analyze, improve and manage business processes across the organization. Literature suggests that a relation between BPM maturity and innovation could exist and recommends more research in specific sectors. Specifically, the financial sector is facing a fintech revolution, putting an enormous pressure on how they deal with technology innovation, process disruption and service transformation. Therefore, the objective of this research is to determine the relation between business process management maturity and innovation in the financial sector. Data was collected using a survey at a large financial enterprise in Europe, resulting in sixty-eight responses. Regression analysis shows that $20.6 \%$ of the variance in innovation can be explained by BPM maturity.
\end{abstract}

\section{KEYWORDS}

Business Process Management, BPM-Maturity, Innovation, Innovation Value Chain, Innovation Adoption

\section{INTRODUCTION}

We are living in an increasingly globalizing world (Steger, 2017). This process of globalization generates increased competition between organizations, forcing them to boost their productivity on one hand, and to innovate on the other (Sanders Jones \& Linderman, 2014; Tidd \& Bessant, 2013). Therefore, existing processes need to be continuously managed and improved in line with strategic aims (Hung, 2006). For this Business Process Management (BPM) can be used. BPM includes activities to analyze, improve and manage organizational processes (Rosemann \& De Bruin, 2005b). In recent years, BPM gained broader attention (Plattfaut, Niehaves, Pöppelbuß, \& Becker, 2011; Ravesteyn, Zoet, Spekschoor, \& Loggen, 2012; Rosemann $\&$ vom Brocke, 2010). Several studies identified a positive relation between BPM and competitive advantage (Ravesteijn, Smit, \& McGuinness, 2016; Tang, Pee, \& Iijima, 2013). Aside from managing efficiency and time-to-market, innovation is a key factor to remain competitive in the contemporary market (Porter, 2008; Roberts, 1998). In the financial sector, organizations are facing a fintech revolution which includes three forces: technology innovation, process disruption and service transformation (Gomber, Kauffman, Parker, $\&$ Weber, 2018). Fintech describes an emerging financial services sector in the 21 st century and includes any technological innovation in this sector (Investopedia, 2018). According to Gomber et al. (2018), this is changing financial service operations in dramatic ways. To cope with this, organizations need to focus on BPM and innovation. However, it is unclear how both concepts relate to each other. BPM can be important for enabling innovation and a positive relation was already identified, although sector-specific research was suggested (Cats \& Ravesteyn, 2017). Since the financial sector is facing a fintech revolution, both BPM and innovation are important topics in this sector. Therefore, this study investigates the relation between these two topics at a large financial enterprise located in Europe. This leads to the main research question: "What is the relation between business process management maturity and innovation in the financial sector?". 


\section{LITERATURE REVIEW}

In this section the main constructs of this study are briefly explained, as well as the conceptual model.

\subsection{Business Process Management Maturity}

Although organizations have many business processes, they differ in how they manage business processes and incorporate these in their departments. Companies that use a BPM methodology have a process-based instead of a siloed department-based view on the activities they execute for their customers (Van Looy, De Backer, Poels, \& Snoeck, 2013). Furthermore, organizations implementing BPM have a competitive advantage (Fisher, 2004). Additionally, business users are expected to be more engaged in setting up, changing and measuring the running business when undertaking BPM (Craggs, 2010; Miers, Harmon, \& Hall, 2005).

Models exist to assess the maturity of an organization implementing BPM (Fisher, 2004; Ravesteyn et al., 2012; Rosemann \& De Bruin, 2005a). This list of BPM-maturity (BPMM) models is rapidly increasing, but the validity and use of these models is still limited (Tarhan, Turetken, \& Reijers, 2016). Several of these BPMM models use levels to describe the maturity plateau of an organization, such as Shafiei and Hajiheydari (2014). In contrast to one-dimensional BPMM models there are multi-dimensional BPMM models, consisting of different dimensions that influence the BPMM level of an organization. For example, the Business Process Maturity Model by Rosemann \& De Bruin (2005b), consisting of the dimensions factor, maturity stage, organizational entity scope, time scope, coverage and proficiency. Additionally, Ravesteyn et al. (2012) presented a BPMM model based on the Capability Maturity Model Integrated (CMMI) and previous models (Rosemann \& De Bruin, 2005b; Rosemann, De Bruin, \& Hueffner, 2004; Rosemann, De Bruin, \& Power, 2006). This BPMM model consists of seven dimensions, which are:

- Process awareness: Refers to a clear relation between the strategy and goals of the organization and business processes, with active involvement of both (executive) management as well as employees.

- Process description: Includes whether processes are transparent by capturing them in process models, defining roles, tasks, responsibilities and guidelines in relation to the strategy.

- Measurement of processes: Covers that for each process in- and outputs are defined, key performance indicators (KPIs) are known, and responsibilities for the process KPIs are clear.

- Management of processes: Relates to the fact that it is clear who is responsible for how process design, analyses, implementation, execution, and improvement is done.

- Process improvement: Relates to the fact that the organization strives to continuously improve processes and actively plans and manages the improvement process.

- Process resources and knowledge: Covers that the right people (with required competencies) and resources (money, facilities, systems) are provided to execute or improve a process according to its goals.

- Information Technology: Covers whether appropriate information systems support the BPM lifecycle.

Because the BPMM model of Ravesteyn et al. (2012) was used and validated in several studies (Cats \& Ravesteyn, 2017; De Waal, Valladares, \& Ravesteyn, 2017; Roslyakova \& Ravesteyn, 2017; Widmann, de Waal, \& Ravesteyn, 2018), it has been selected to form the BPM-maturity construct in the conceptual model of this research.

\subsection{Innovation}

Innovation is often confused with invention, according to Tidd and Bessant (2013). They state that invention is having a new idea, whereas innovation is the process of turning an idea into reality to capture value from it. This innovation process can focus on introducing something new and improving existing solutions (Kirchmer, 2017a; Rothwell \& Gardiner, 1985; Tidd \& Bessant, 2013). However, innovation relates to the adoption of innovations as well (Rogers, 2003). These two views on innovation are discussed in the following sections. 


\subsection{Innovation Value Chain}

The innovation value chain (IVC) focusses on innovation as a production process. IVC is a sequential set of stages related to innovation, and although several studies in the literature mention innovation stages, they have their own perspective on this topic. An example IVC is presented by Van Horne et al. (2006) and is based on Porter's generic value chain (Porter, 1985). Porter's value chain describes the activities an organization undertakes to deliver value for its customers. In other IVC related studies, innovation is described from a knowledge perspective, consisting of knowledge sourcing, transformation and exploitation (Ganotakis \& Love, 2012; Roper, Du, \& Love, 2008).

IVC as a more generic model towards innovation is presented by Hansen and Birkinshaw (2007), which is a tailored, end-to-end approach for generating, converting and diffusing ideas. Their IVC starts with the idea generation phase, where novel ideas are born inside the company or with parties outside the company. The second phase, idea conversion, covers selecting the ideas and translating them into solutions. During diffusion in the final phase, the result is spread across the organization. Furthermore, Hansen and Birkinshaw (2007) proposed a questionnaire to rate the IVC of a company. Because of the comprehensiveness of the IVC of Hansen and Birkinshaw (2007), it is selected as part of our innovation construct in the conceptual model.

\subsection{Innovation Adoption}

Through the years, the adoption of innovation was studied widely resulting in many related theories. The Theory of Reasoned Action (TRA) is an important Innovation adoption (IA) model mentioned in the literature, which focuses on an individual's voluntary behavior (Ajzen \& Fishbein, 1980; Fishbein \& Ajzen, 1975). An extension of the TRA is the Theory of Planned Behavior (TPB), which describes the relation between someone's intention and behavior (Ajzen, 1991). Although the TRA and TPB were outstanding in explaining the individuals behavior in general, it lacked specific knowledge on the implementation of information technology solutions. Therefore, Davis Jr. (1985) introduced the Technology Acceptance Model (TAM), an IA model for empirically testing new end-user information systems. Although the TAM is focused on the attitude of an individual towards new technology, it doesn't take social factors into consideration. Therefore, the Diffusion of Innovation Theory (DOI) of Rogers (2003) describes how the adoption of innovation is dispersed among a group.

Based on TPB (Ajzen, 1985) and DOI (Rogers, 2003), Tan and Teo (2000) investigated the factors influencing the adoption of internet banking (FAIB). The results of this study is the FAIB framework that shows that attitudinal and perceived behavioral control factors, rather than social influence, play a significant role in influencing the intention to adopt Internet banking. Because the FAIB is an extended version of the renowned existing TPB and DOI models, its factors were selected to be used in the conceptual model of this study.

\subsection{Conceptual Model}

Based on the two main topics discussed in the previous sections, a conceptual model was constructed to investigate the relation between BPMM and innovation (see Figure 1). The first part of the conceptual model is the BPMM model of Ravesteyn et al. (2012), including the seven BPMM dimensions. The other part of the model is innovation (the dependent variable), which is based on the previously described IVC (Hansen \& Birkinshaw, 2007) and IA (Tan \& Teo, 2000). IVC contains the Idea generation, Idea conversion and Idea diffusion dimensions (Hansen \& Birkinshaw, 2007). IA consists of three dimensions, namely attitude to innovation, subjective norms and perceived behavioral control (Tan \& Teo, 2000). 


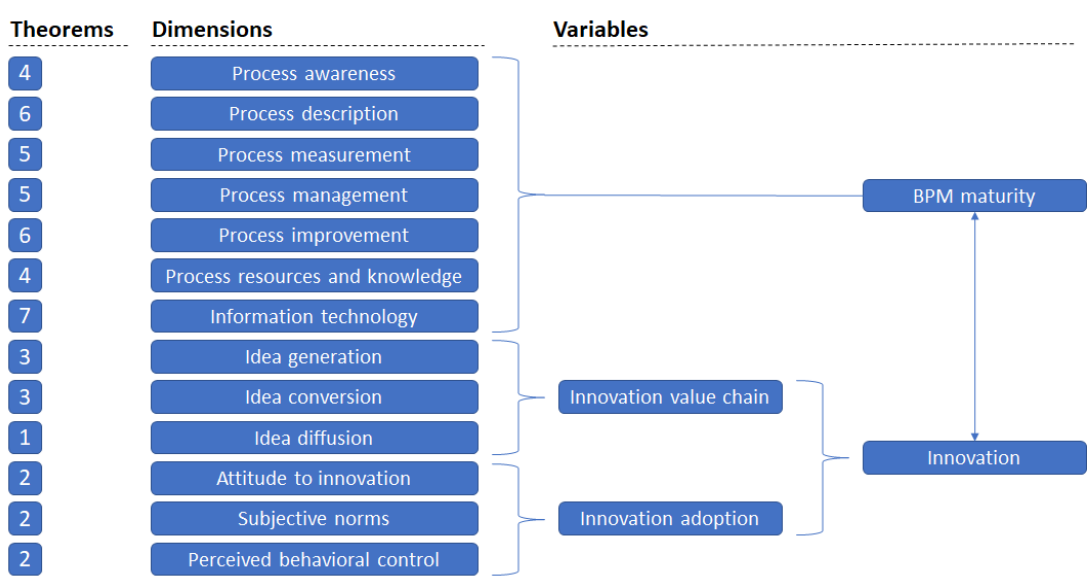

Figure 1. Conceptual Model - Relation between BPM Maturity and innovation (Cats \& Ravesteyn, 2017)

Seven hypotheses were defined, which are depicted in Figure 2. The hypotheses are:

H1. There is a significant positive relation between process awareness and innovation.

$\mathrm{H} 2$. There is a significant positive relation between process description and innovation.

H3. There is a significant positive relation between process measurement and innovation.

H4. There is a significant positive relation between process management and innovation.

H5. There is a significant positive relation between process improvement and innovation.

H6. There is a significant positive relation between process resources and knowledge and innovation.

H7. There is a significant positive relation between information technology and innovation.

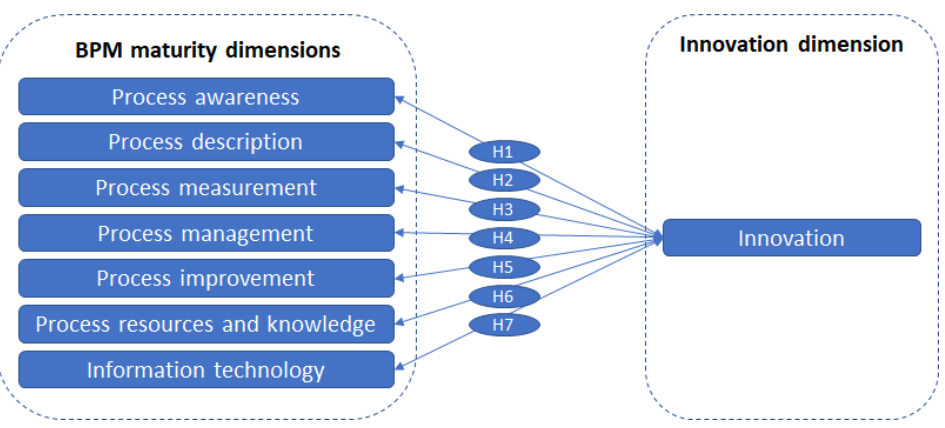

Figure 2. Hypotheses between BPM Maturity Dimensions and Innovation Dimensions

\section{RESEARCH METHOD}

This study is a cross-sectional exploratory research (Bryman \& Bell, 2015). To get more knowledge on the relation between BPMM and innovation within the financial sector, a large financial enterprise located in Europe was willing to participate in this study by allowing data collection within their organization. The collected data was analyzed using IBM SPSS Statistics version 25 and included descriptive statistics, data validation analysis, factor analysis, correlation analysis and regression analysis.

\subsection{Data Collection}

For this study, data was collected using a survey. Approximately 500 employees from the contributing financial organization were invited, resulting in 68 valid responses. No missing responses were received, because all the questions in the survey were required before it could be submitted. This resulted in 68 cases used for analysis. 


\subsection{Questionnaire}

The questionnaire was based on an existing validated questionnaire (Roslyakova \& Ravesteyn, 2017). Respondents were provided with an introduction on the study, the questionnaire setup, an ethical statement and the invitation to participate. Subsequently, organization specific questions meant for descriptive analysis purposes were given, followed by questions on the respondents view on BPM definitions and their BPM knowledge level. Finally, the current situation within the organization related to process maturity and innovation was asked.

\subsection{Measurement and Validation}

Data validation analysis was conducted to verify the internal consistency of the dimensions based on the collected data. To verify this, the distribution of the 50 Likert scale measured theorems on the BPMM and innovation dimensions was validated by calculating the Cronbach's alpha for each set of questions (Cronbach, 1951; Nunnally \& Bernstein, 1994; Tavakol \& Dennick, 2011), see table 1.

Table 1. Reliability Analysis on the BPMM and Innovation Dimensions

\begin{tabular}{lll}
\hline Dimension & Cronbach's alpha & Number of items \\
\hline Process Awareness & 0.692 & 4 \\
Process Description & 0.747 & 6 \\
Process Measurement & 0.807 & 5 \\
Process Management & 0.773 & 5 \\
Process Improvement & 0.782 & 6 \\
Process Resources and Knowledge & 0.462 & 4 \\
Information Technology & 0.692 & 7 \\
Innovation Value Chain & 0.780 & 7 \\
Innovation Adoption & 0.595 & 6 \\
\hline
\end{tabular}

Considering the analyzed dimensions, most of the BPMM sub-dimensions had a Cronbach's alpha score greater than 0.7, which implies an acceptable or good internal consistency (Tavakol \& Dennick, 2011). Both the process awareness and information technology dimension were indicated as questionable but close enough to be acceptable. Although process resources and knowledge was identified as unacceptable $(\alpha=0.462)$, the BPMM dimensions were previously identified as reliable (Cats \& Ravesteyn, 2017; De Waal et al., 2017) and therefore used for further analysis. The poor and questionable alpha score of IA $(\alpha=0.595)$ was expected to be related to the innovation statements setup in the questionnaire (Cats \& Ravesteyn, 2017; Widmann et al., 2018).

\subsection{Analysis Techniques}

Correlation analysis was used to determine the relationship between the main dimensions of this study, namely BPMM and innovation, and its sub-dimensions (Field, 2013). Because a scatter plot displayed a linear cohesion between the variables, the strength of the cohesion was calculated using Pearson's correlation and interpreted (Evans, 1996). Subsequently, to identify to what extent innovation could be predicted by the BPM-maturity level, regression analysis is conducted (Field, 2013) with innovation, IVC and IA as dependent variables and the BPMM dimensions as the independent variables.

\section{FINDINGS AND DISCUSSION}

Between BPMM and innovation a moderate positive relation was identified $(r=0.454 ; p=0.000)$, which was observed in previous studies as well (Ravesteijn et al., 2016; Widmann et al., 2018), see table 2. Of all the BPMM dimensions, process awareness had the strongest relation to innovation and the sub-dimensions IA and IVC. Process awareness had a moderate relation with innovation in general $(r=0.545 ; p=0.000)$, followed 
by a moderate positive relationship with IVC $(r=0.529 ; p=0.000)$ and a weak relation with IA $(r=0.274$; $p=0.024)$. The moderate relation between process awareness and innovation implies that organizations who understand the relation between strategy and goals of business processes and who have everyone actively involved, are good in developing and adopting new ideas. This correlation was identified in previous studies as well (Ravesteijn et al., 2016; Widmann et al., 2018), and confirms hypothesis 1. Between the IVC and BPMM a moderate positive relation was identified $(r=0.459 ; p=0.000)$, in accordance with the results observed in previous studies (Ravesteijn et al., 2016; Widmann et al., 2018). Furthermore, all BPMM dimensions except information technology were identified as having a significant positive relation with IVC, which was in accordance with the study of Widmann et al. (2018). This implies that companies where BPMM disciplines are executed, better understand how to generate, convert and diffuse ideas. Kirchmer (2017b) endorsed this result by mentioning BPM as a method for the structured setup of a company's innovation discipline.

Process awareness compared to the other BPMM dimensions was identified as having the strongest relation to the IVC dimensions. These process awareness relations were respectively moderate when related to idea generation $(r=0.441 ; p=0.000)$, moderate related to idea conversion $(r=0.432 ; p=0.000)$, and to idea diffusion a weak relation was identified $(r=0.398 ; p=0.001)$. These findings imply that organizations willing to generate and distribute new ideas and considering investing in BPM, should start with increasing process awareness. This increase of process awareness requires organizations to deeply connect their strategy and goals to their business processes, and furthermore make sure everyone in the company is involved in these processes. However, this implication is not supported in the study of Tang et al. (2013), because they found no significant relation between the process view of an employee and employee innovativeness.

The correlation analysis on the IA sub-dimensions revealed that only perceived behavioral control had a significant positive relation with BPMM $(r=0.382 ; p=0.001)$. Furthermore, four out of seven BPMM sub-dimensions were identified as significant positive related to perceived behavioral control. Consequently, a significant positive relation between BPMM and perceived behavioral control implies that organizations who are aware of their described processes, their employees stronger belief they have control over the external and personal factors that may facilitate or constrain the innovation use. However, continuously improving processes and having the right resources and knowledge, does not necessarily mean that employees belief they have control over the external and personal factors that may facilitate or constrain the innovation use.

Table 2. Correlation analysis on the BPMM vs. innovation, IVC and IA dimensions.

\begin{tabular}{|c|c|c|c|c|c|c|c|c|c|}
\hline & \multirow[b]{2}{*}{ 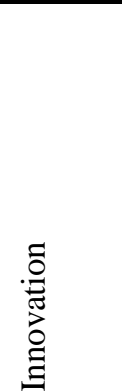 } & \multicolumn{2}{|c|}{$\begin{array}{l}\text { Innovation } \\
\text { dimensions }\end{array}$} & \multicolumn{3}{|c|}{$\begin{array}{c}\text { Innovation Value Chain } \\
\text { dimensions } \\
\end{array}$} & \multicolumn{3}{|c|}{$\begin{array}{l}\text { Innovation adoption } \\
\text { dimensions }\end{array}$} \\
\hline & & 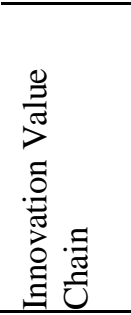 & 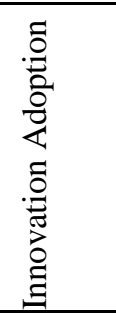 & 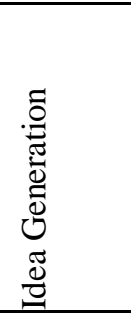 & 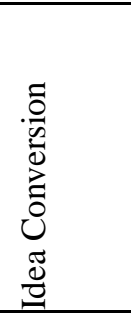 & 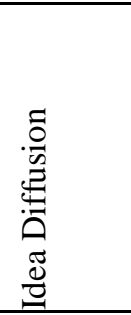 & 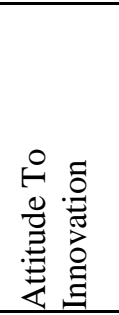 & 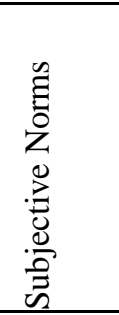 & 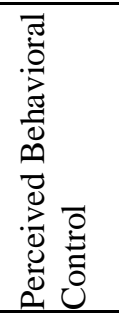 \\
\hline BPM Maturity & $0,454^{* *}$ & $0,459^{* *}$ & 0,206 & $0,367^{* *}$ & $0,400^{* *}$ & $0,316^{* *}$ & $-0,058$ & 0,088 & $0,382^{* *}$ \\
\hline Process Awareness & $0,545^{* *}$ & $0,529^{* *}$ & $0,274^{*}$ & $0,441^{* *}$ & $0,432^{* *}$ & $0,398^{* *}$ & $-0,063$ & 0,134 & $0,480^{* *}$ \\
\hline Process Description & $0,372^{* *}$ & $0,315^{* *}$ & $0,244^{*}$ & $0,265^{*}$ & $0,249^{*}$ & $0,250^{*}$ & $-0,007$ & 0,142 & $0,360^{* *}$ \\
\hline Process & $0,325^{* *}$ & $0,355^{* *}$ & 0,115 & $0,319^{* *}$ & $0,285^{*}$ & 0,229 & 0,000 & 0,007 & 0,226 \\
\hline Measurement & & & & & & & & & \\
\hline Process Management & $0,245^{*}$ & $0,269^{*}$ & 0,086 & 0,209 & $0,243^{*}$ & 0,175 & $-0,138$ & 0,084 & 0,215 \\
\hline Process Improvement & $0,419^{* *}$ & $0,425^{* *}$ & 0,188 & $0,381^{* *}$ & $0,357^{* *}$ & 0,236 & $-0,068$ & 0,118 & $0,325^{* *}$ \\
\hline Process Resources & $0,361^{* *}$ & $0,436^{* *}$ & 0,076 & $0,379^{* *}$ & $0,358^{* *}$ & $0,290^{*}$ & $-0,144$ & $-0,067$ & $0,351^{* *}$ \\
\hline And Knowledge & & & & & & & & & \\
\hline $\begin{array}{l}\text { Information } \\
\text { Technology }\end{array}$ & 0,204 & 0,205 & 0,095 & 0,034 & $0,277^{*}$ & 0,170 & 0,053 & 0,002 & 0,143 \\
\hline
\end{tabular}


A summary of the regression analysis is shown in table 3. In relation to the dependent variables (innovation, IVC and IA variable) only significant BPM dimensions are listed.

Table 3. Regression Analysis between the Innovation Dimensions and the BPMM Dimensions

\begin{tabular}{llllllll}
\hline Dependent variable & Predictor & $B$ & $S E B$ & $\beta$ & $t$ & $P$ & $r^{2}$ \\
\hline Innovation & BPM Maturity & 0.431 & 0.104 & 0.454 & 4.142 & $0.000^{* *}$ & 0.206 \\
& Process Awareness & 0.312 & 0.103 & 0.498 & 3.040 & $0.004^{* *}$ & \\
Innovation Value Chain & BPM Maturity & 0.586 & 0.140 & 0.459 & 4.198 & $0.000^{* *}$ & 0.211 \\
& Process Awareness & 0.368 & 0.138 & 0.437 & 2.658 & $0.010^{*}$ & \\
Innovation Adoption & BPM Maturity & 0.250 & 0.146 & 0.206 & 1.710 & 0.092 & 0.042 \\
\hline$* * \mathrm{p}<0.01 ; * \mathrm{p}<0.05$ & & & & & & &
\end{tabular}

The results from the regression analysis show that $20.6 \%$ of the variance in innovation can be explained by changes in BPMM $\left(r^{2}=0.206\right)$. However, $79,4 \%$ of the variance in innovation is not explained by changes in BPMM. This implies organizations improving innovation are expected to partially realize this by investing in BPM capabilities.

Process awareness is the only BPM dimension being statistically significant for innovation $(\beta=0.498$; $p=0.004)$ and IVC $(\beta=0.437 ; p=0.010)$. These moderate strong relationships (Cohen, 1988) confirm the previous findings on the correlation of process awareness. This implies that organizations who want to improve on innovation, can predict $49.8 \%$ of this change by providing a clear relation between their organizations strategy, goals and business processes, and having all employees actively involved. Additionally, organizations improving their procedure of idea generation, conversation and diffusion, can explain $43.7 \%$ of this variance from process awareness.

\section{CONCLUSIONS AND RECOMMENDATIONS}

The objective of this research was to determine the relation between BPMM and innovation in the financial sector. Therefore, the main research question was: "What is the relation between business process management maturity and innovation in the financial sector?". To answer this question seven hypotheses were formulated. Table 4 lists whether these hypotheses were supported.

Table 4. Hypotheses Testing Results of the Relation between BPMM and Innovation

\begin{tabular}{|c|c|c|}
\hline Hypothesis & $\begin{array}{l}\text { Correlation } \\
\text { coefficient }\end{array}$ & Test result \\
\hline H1. Significant positive relation between process awareness and innovation & $0.545^{* *}$ & Supported \\
\hline H2. Significant positive relation between process description and innovation & $0.372^{* *}$ & Supported \\
\hline $\begin{array}{l}\text { H3. Significant positive relation between process measurement and } \\
\text { innovation }\end{array}$ & $0.325^{* *}$ & Supported \\
\hline $\begin{array}{l}\text { H4. Significant positive relation between process management and } \\
\text { innovation }\end{array}$ & $0.245^{*}$ & Supported \\
\hline $\begin{array}{l}\text { H5. Significant positive relation between process improvement and } \\
\text { innovation }\end{array}$ & $0.419^{* *}$ & Supported \\
\hline $\begin{array}{l}\text { H6. Significant positive relation between process resources and knowledge } \\
\text { and innovation }\end{array}$ & $0.361^{* *}$ & Supported \\
\hline $\begin{array}{l}\text { H7. Significant positive relation between information technology and } \\
\text { innovation }\end{array}$ & 0.204 & Not Supported \\
\hline
\end{tabular}

Based on the correlation analysis a moderate positive relation between BPMM and innovation is identified. Between BPMM and IVC a moderate positive relation is identified. Overall, no significant relation is identified between BPMM and IA, only significant relations between BPMM sub-dimensions and sub-dimensions of IA are found. Furthermore, to predict whether changes in innovation are related to 
changes in BPMM, regression analysis was conducted. $49.8 \%$ of the variance in innovation was predicted from process awareness, $43.7 \%$ of the variance in IVC was predicted from process awareness.

The findings imply that organizations willing to improve their innovation process, are advised to invest in increasing their BPM maturity. The most important part of this investment is making people aware of the processes. Remaining investments should focus on describing, measuring, managing and continuously improving business process. Finally, they should make sure the right people and resources are in place. However, based on this study we find that investing in BPM is not enough to increase the innovation capability of the organization.

Because this study was set up as a cross-sectional research, data was collected using a snapshot in time which is a limitation to the study. Another limitation is the data being collected from only one large financial enterprise with its head office located in The Netherlands. Because the respondents were mostly located in The Netherlands $(82.4 \%)$ and worked for the IT department of the organization $(51.5 \%)$, generalization of the results can only be done conservative.

Based on data validation, subsequent research is suggested to improve the process resources and knowledge dimension. Also, based on the factor analysis, future research to improve the innovation part of the conceptual model is suggested. Considering $79.4 \%$ of the variance in innovation was not explained based on the model of this study, future research is advised to be conducted regarding BPMM and innovation to constitute a better understanding of the relation between these dimensions. Furthermore, because regression analysis showed that process awareness was the only BPMM dimension being statistically significant for innovation, future research is suggested to identify which activities make this relation that strong. Combining data from previous studies regarding the relation between BPMM and innovation is recommended for conducting advanced analysis such as structural equation modeling. Finally, additional research is suggested on this main topic for different organizations and sectors.

\section{REFERENCES}

Ajzen, I. (1985). From Intentions to Actions: A Theory of Planned Behavior. In Action Control (pp. 11-39). Berlin, Heidelberg: Springer Berlin Heidelberg.

Ajzen, I. (1991). The Theory of Planned Behavior. Organizational Behavior and Human Decision Processes, 50(2), 179-211.

Ajzen, I., \& Fishbein, M. (1980). Understanding attitudes and predicting social behaviour. Prentice-Hall.

Bryman, A., \& Bell, E. (2015). Business research methods (4th ed.). Oxford University Press.

Cats, T., \& Ravesteyn, P. (2017). The Relation Between Process Management and Innovation - A comparison of the IT and Manufacturing industries. In 30th Bled eConference (pp. 1-13).

Cohen, J. (1988). Statistical power analysis for the behavioral sciences (2nd ed.). Taylor \& Francis.

Craggs, S. (2010). Comparing BPM from IBM, Software AG and Pegasystems.

Cronbach, L. J. (1951). Coefficient alpha and the internal structure of tests. Psychometrika, 16(3), 297-334.

Davis Jr., F. D. (1985). A technology acceptance model for empirically testing new end-user information systems: Theory and results. B.S., Industrial Engineering, Wayne State University.

De Waal, B. M. E., Valladares, R., \& Ravesteyn, P. (2017). BPM Maturity and Process Performance: The case of the Peruvian Air force Full Paper. In Twenty-third Americas Conference on Information Systems (pp. 1-10).

Evans, J. D. (1996). Straightforward statistics for the behavioral sciences. Pacific Grove: Brooks/Cole.

Field, A. P. (2013). Discovering statistics using IBM SPSS Statistics (4th ed.). SAGE Publications Ltd.

Fishbein, M., \& Ajzen, I. (1975). Belief, Attitude, Intention, and Behavior: An Introduction to Theory and Research. Addison-Wesley Pub. Co.

Fisher, D. M. (2004). The Business Process Maturity Model: A Practical Approach for Identifying Opportunities for Optimization. BPTrends, September, 1-7.

Ganotakis, P., \& Love, J. H. (2012). The Innovation Value Chain in New Technology-Based Firms: Evidence from the U.K. The Journal of Product Innovation Management, 29(5), 839-860.

Gomber, P., Kauffman, R. J., Parker, C., \& Weber, B. W. (2018). On the Fintech Revolution: Interpreting the Forces of Innovation, Disruption, and Transformation in Financial Services. JMIS, 35(1), 220-265.

Hansen, M. T., \& Birkinshaw, J. (2007). The Innovation Value Chain. Harvard Business Review, 85.6(June 2007), $121-130$

Hung, R. Y.-Y. (2006). Business Process Management as Competitive Advantage: a Review and Empirical Study. Total Quality Management \& Business Excellence, 17(1), 21-40. 
Investopedia. (2018). Fintech Definition. Retrieved July 9, 2018, from https://www.investopedia.com/terms/f/fintech.asp Kirchmer, M. (2017a). High Performance Through Business Process Management: Strategy Execution in a Digital World (3rd ed.). Cham: Springer International Publishing.

Kirchmer, M. (2017b). Innovation: Enabled by Process Management. In High Performance Through Business Process Management (pp. 29-46). Cham: Springer International Publishing.

Miers, D., Harmon, P., \& Hall, C. (2005). The 2007 BPM suites report. Business Process Trends: Version, 1.

Nunnally, J. C., \& Bernstein, I. H. (1994). Pychometric Theory (Third Edit). McGraw-Hill.

Plattfaut, R., Niehaves, B., Pöppelbuß, J., \& Becker, J. (2011). Development of BPM Capabilities-Is Maturity the Right Path? In European Conference on Information Systems (ECIS) (pp. 1-13).

Porter, M. E. (1985). Competitive Advantage: Creating and Sustaining Superior Performance. Free Press.

Porter, M. E. (2008). Competitive Strategy: Techniques for Analyzing Industries and Competitors. Simon and Schuster.

Ravesteijn, P., Smit, J., \& McGuinness, B. (2016). A study on the relation between business process management maturity and innovation. 22nd Americas Conference on Information Systems, 1-10.

Ravesteyn, P., Zoet, M., Spekschoor, J., \& Loggen, R. (2012). Is There Dependence Between Process Maturity and Process Performance? Communications of the IIMA, 12(2), 65-80.

Roberts, R. (1998). Managing innovation: The pursuit of competitive advantage and the design of innovation intense environments. Research Policy, 27(2), 159-175.

Rogers, E. M. (2003). Diffusion of Innovations (5th ed.). Free Press.

Roper, S., Du, J., \& Love, J. H. (2008). Modelling the innovation value chain. Research Policy, 37(6-7), 961-977.

Rosemann, M., \& De Bruin, T. (2005a). Application of a Holistic Model for Determining BPM Maturity. BPTrends, February, 1-21.

Rosemann, M., \& De Bruin, T. (2005b). Towards a Business Process Management Maturity Model. In ECIS 2005 Proceedings of the Thirteenth European Conference on Information Systems. Regensburg.

Rosemann, M., De Bruin, T., \& Hueffner, T. (2004). A Model for Business Process Management Maturity. In Australasian (ACIS) (p. 7).

Rosemann, M., De Bruin, T., \& Power, B. (2006). A model to measure business process management maturity and improve performance. Business Process Management, 299-315.

Rosemann, M., \& vom Brocke, J. (2010). The Six Core Elements of Business Process Management. In Handbook on Business Process Management 1 (pp. 107-122). Berlin, Heidelberg: Springer Berlin Heidelberg.

Roslyakova, L., \& Ravesteyn, P. (2017). Relation between Business Process Management Maturity and Innovation. In 13th European Conference on Management, Leadership and Governance: ECMLG 2017 (pp. 434-443).

Rothwell, R., \& Gardiner, P. (1985). Invention, innovation, re-innovation and the role of the user: A case study of British hovercraft development. Technovation, 3(3), 167-186.

Sanders Jones, J. L., \& Linderman, K. (2014). Process management, innovation and efficiency performance: The moderating effect of competitive intensity. Business Process Management Journal, 20(2), 335-358.

Shafiei, A., \& Hajiheydari, N. (2014). Developing a business process management maturity model: A study of 300 Iranian superior companies. International Journal of Engineering and Technical Research (IJETR), 2(10), 231-242.

Steger, M. B. (2017). Globalization: A very short introduction (Vol. 86). Oxford University Press.

Tan, M., \& Teo, T. (2000). Factors Influencing the Adoption of Internet banking. Journal of the Association for Information Systems (JAIS), 1(5), 1-42.

Tang, J., Pee, L. G., \& Iijima, J. (2013). Investigating the effects of business process orientation on organizational innovation performance. Information \& Management, 50(8), 650-660.

Tarhan, A., Turetken, O., \& Reijers, H. A. (2016). Business process maturity models: A systematic literature review. Information and Software Technology, 75, 122-134.

Tavakol, M., \& Dennick, R. (2011). Making sense of Cronbach's alpha. International Journal of Medical Education, 2 , 53-55.

Tidd, J., \& Bessant, J. (2013). Managing Innovation: Integrating Technological, Market and Organizational Change (5th ed.). John Wiley \& Sons.

Van Horne, C., Frayret, J.-M., \& Poulin, D. (2006). Creating value with innovation: From centre of expertise to the forest products industry. Forest Policy and Economics, 8(7), 751-761.

Van Looy, A., De Backer, M., Poels, G., \& Snoeck, M. (2013). Choosing the right business process maturity model. Information \& Management, 50(7), 466-488.

Widmann, V., de Waal, B. M. E., \& Ravesteyn, P. (2018). How Do BPM Maturity and Innovation Relate in Large Companies? In World Conference on Information Systems and Technologies (pp. 87-96). Springer. 